\title{
Dwarfing Effect of Apple Rootstocks Is Intimately Associated with Low Number of Fine Roots
}

\author{
Haishan An, Feixiong Luo, Ting Wu, Yi Wang, Xuefeng Xu, \\ Xinzhong Zhang, and Zhenhai Han ${ }^{1}$ \\ Institute for Horticultural Plants, China Agricultural University, No. 2 \\ Yuanmingyuan West Road, Haidian District, Beijing 100193, P.R. China
}

Additional index words. dwarfing, fine root, interstems, Malus robusta Borkh., rootstock

\begin{abstract}
Fine root ( $\leq 2 \mathrm{~mm}$ in diameter) systems play a pivotal role in water and mineral uptake in higher plants. However, the impact of fine root architecture on tree growth and development is not fully understood, especially in apple trees. Here, we summarize a 6-year-trial study using minirhizotrons to investigate the relationships between fine root production, mortality, and longevity in 'Red Fuji' trees grafted on five different rootstocks/interstems. Based on root length density (RLD), fine root production and mortality were markedly lower in 'Red Fuji' trees growing on dwarfing M.9 (M.9) and Shao series no. 40 (SH.40) rootstocks than in trees on standard Malus robusta'Baleng Crab' (BC) rootstock. The use of M.9 and SH.40 as interstems led to an extensive reduction in fine root production and mortality in comparison with $\mathrm{BC}$ rootstock. Root number density (RND), but not average root length (ARL), showed similar patterns to RLD. About one-half of fine roots in 'Red Fuji' tree growing on M.9 were scattered within the top $0-20 \mathrm{~cm}$ of topsoil, indicating shallow root system in M.9, whereas in trees on BC, $55.15 \%$ of fine roots were distributed between 100- and 150-cm soil depth, indicating a deep root architecture. The addition of interstems did not alter fine root soildepth distribution. For all rootstocks/interstems, fine roots with a life span of less than 80 days were generated in spring and summer, but fine roots which lived for more than 81 days were produced almost all the year round. In conclusion, lower fine root numbers were associated with the dwarfing effect in dwarfing rootstocks/interstems, but ARL and shallower rooting were not.
\end{abstract}

Fine roots ( $\leq 2 \mathrm{~mm}$ in diameter), responsible for water and nutrient uptake, play an important role in tree growth and development (Makkonen and Helmisaari, 2001; Noguchi et al., 2005). Fine root traits (e.g., diameter, life span, and rooting depth) impact the reproductive and vegetative growth of apple trees (Yao et al., 2006). Detailed knowledge about fine root production, mortality, and spatial distribution of dwarfing rootstocks is currently insufficient to understand the dwarfing mechanism.

Despite the importance of fine roots, knowledge of their roles in productivity is limited due to the methodological difficulties involved in observing fine roots in situ (Laiho et al., 2014; Olesinski et al., 2012). The invention of minirhizotrons facilitates repeated and noninvasive measurement of fine

Received for publication 16 Nov. 2016. Accepted for publication $28 \mathrm{Jan} .2017$.

We thank for the funding of Special Fund for Agro-scientific Research in the Public Interest (201203075); the Modern Agricultural Industry Technology System (CARS-28); Key Laboratory of Biology and Genetic Improvement of Horticulture Crop (Nutrition and Physiology), Ministry of Agriculture, and Beijing Collaborative innovation center for eco-environmental improvement with forestry and fruit trees.

${ }^{1}$ Corresponding author. E-mail: rschan@cau.edu. cn. roots in situ and has been widely used in many annual and perennial plants (Johnson et al., 2001; Liedgens and Richner, 2001; Majdi, 1996; Majdi et al., 2005; Pateña and Ingram, 2000). Fine root production and mortality always occur simultaneously; they can be quantified indirectly using changes in root length or RLD [which indicates root length (meters) per unit volume of the sampled soil (cubic meters)] (Hulugalle et al., 2015; Majdi and Andersson, 2005; Noguchi et al., 2004, 2005). RLD is the most commonly used parameter in fine root measurement to represent the quantity of fine roots (Ahmadi et al., 2014; Makita et al., 2009). Because it is not easy to define roots as dead or alive accurately using minirhizotrons when digitizing root segments, instead time to disappearance of a root segment is usually used to define the fine root life span (Ahrens et al., 2014; Gaul et al., 2009; Withington et al., 2006).

Rootstocks can evidently influence the production and distribution of fine roots in grafted plants in many species (Black et al., 2010). Apple trees grafted on semidwarfing M.26 and semivigorous MM.106 rootstocks have been shown to have higher RLDs and a more vertical distribution of roots than those on dwarfing rootstock Mark (De Silva et al., 1999). Moreover, apple trees grown on dwarfing M.9 rootstock show reduced root growth compared with those grown on semivigorous MM.106 (Bianco et al., 2003). We have previously shown that RLDs of apple trees on both dwarfing rootstocks (M.9 and SH.40) and trees with M.9 and SH.40 as interstems were apparently lower than RLDs of trees on standard rootstock BC (Ma et al., 2013). RLD is a multifactorial parameter and is the outcome not only of fine root number, single root length, and spatial distribution, but also of fine root turnover rate, longevity, time to emerge, and time to disappear. Therefore, whether and how rootstock affects fine root production, mortality, longevity, and/or distribution remain unclear.

Fine root diameter and life span also vary among rootstocks. Fine roots of peach on semidwarfing rootstock K.146-43 have been found to be thinner than those on vigorous rootstock Nemaguard and semivigorous rootstocks K.119-50, P.30-135, and Hiawatha (Basile et al., 2007). Similarly, fine root longevity of apple trees grown on dwarfing rootstock M.9 is shorter than those grafted on more vigorous rootstocks (Garcia-Villanueva et al., 2004; Hou et al., 2012). Fine root life span in apple trees on semidwarfing rootstocks M.7 and G.30 was found to be shorter than those on another semidwarfing rootstock CG.6210 under the same soil conditions (Yao et al., 2006).

Crop load also influences fine root production. One major new root emergence event in May to July has been recorded in nonfruit-bearing years, while there was no obvious peak in new root occurrence during fruit-bearing years in apple trees on both semidwarfing M.7 and G.30 and another semidwarfing CG.6210, indicating the suppression of root production by fruit load (Yao et al., 2006). Root growth varied in plants showing alternate bearing: total root production and growth rates of off-year trees were nearly twice as large as those of on-year Kerman pistachio (Pistacia vera L.) trees grafted on Desf. rootstock (Rosecrance et al., 1996). Furthermore, more roots were observed in light-crop-years than in heavycrop-years apple trees on semidwarfing 'Empire'/M.9/M.111 rootstocks (Yao et al., 2009). In addition, high fruit loads ( $>350$ fruit/ tree) tend to restrain the root growth of 'Elegant Lady' peach tree on 'Lovell' rootstock (Marsal et al., 2003).

To extend our understanding about the potential relationship between dwarfing effects and fine root development and architecture of apple trees on dwarfing rootstocks/ interstems, in a 6-year trial, fine root production and mortality of different apple-grafted combinations based on RLDs, RNDs, and ARL were investigated using minirhizotrons. Fine root longevity, tree growth, and fruit yield traits were also analyzed.

\section{Materials and Methods}

Materials and experimental design. Ten rhizo-pits $(1.5 \times 1.5 \times 3 \mathrm{~m}$, length $\times$ width $\times$ height) were constructed to monitor fine roots. Five layers of horizontal minirhizotron tubes $(178 \mathrm{~cm}$ in length and $5.6 \mathrm{~cm}$ in diameter) were installed before the rhizo-pits 
were filled with premixed substrate. The distances among five tube layers and the ground were 20,60,100,150, and $200 \mathrm{~cm}$, respectively. Each layer contained four symmetrically placed tubes. 'Red Fuji' apple trees were grafted on five treatments with different rootstocks/interstems, two replicates for each type of tree, that is, one standard rootstock $M$. robusta $\mathrm{BC}$, two dwarfing rootstocks M.9 and SH.40, and two treatments with M.9 and SH.40 as interstems of which the rootstock was BC. The experimental design, installation of minirhizotron tubes for fine root observation, and plant management are as described in detail by Hou et al. (2012) and Ma et al. (2013).

Minirhizotron observations. The minirhizotrons were used to observe fine roots in 0to $150-\mathrm{cm}$ soil depth at 10 -d intervals using the ET100 Root Observation System (Bartz Technology Crop, Santa Barbara, CA). Digital images $(18 \times 13.5 \mathrm{~mm})$ were captured by moving the camera along the tubes in 13.5-mm steps using an indexed handle. A total of 98 images were taken per tube. The captured images were analyzed using image analysis software (WinRHIZO Tron MF 2009a; Regent Instruments Inc., Quebec City, Canada).

The data on individual roots were converted to length per unit volume of soil sampled (i.e., RLD, $\mathrm{m} \cdot \mathrm{m}^{-3}$ ), to indicate the actual fine root dynamics more accurately (Fukuzawa et al., 2013). The RLD was calculated according to Eq. (1):

$$
\mathrm{RLD}=\frac{L}{\mathrm{n} A \times \mathrm{ST}}
$$

where $L$ is total root length (m), $\mathrm{n}$ is the numbers of captured images (here $\mathrm{n}=98$ ), $A$ is minirhizotron frame area observed (here $\left.A=18 \times 13.5 \times 10^{-6} \mathrm{~m}^{-2}\right)$, ST is soil thickness observed through the minirhizotrons, here $\mathrm{ST}=2.5 \times 10^{-3} \mathrm{~m}$ (Ma et al., 2013).

RND and ARL were also analyzed in this study. The RND was calculated according to Eq. (2):

$$
\mathrm{RND}=\frac{\mathrm{N}}{\mathrm{n} A \times \mathrm{ST}}
$$

where $\mathrm{N}$ is total fine root number, and $\mathrm{n}, A$, and ST are the same as in Eq. (1). The ARL was calculated according to Eq. (3):

$$
\mathrm{ARL}=\frac{\mathrm{RLD}}{\mathrm{RND}}
$$

where RLD is root length density and RND is root number density.

Fine root production and mortality. For each rhizo-pit, the RLD-based fine root production was calculated as the sum of the RLD of newly emerged roots, representing the gross increase in the RLD of existing roots during each observation interval. Similarly, fine root mortality was evaluated as the sum of RLD of roots that disappeared, to show natural RLD loss from existing roots (Burton et al., 2000; Satomura et al., 2007).

Fine root diameter. The diameter of individual roots was determined when they first occurred, and the mean diameter of fine roots in this study was the average diameter of all observed fine roots.

Fine root longevity. Individual root longevity was calculated as the time interval between the date of the root's first appearance and the date of its disappearance (Anderson et al., 2003; Germon et al., 2016). In this study, fine roots were divided into four subgroups based on their longevity, 0-21, 22-49, $50-80$, and $\geq 81 \mathrm{~d}$.

Tree growth and fruit yield. Tree trunk diameter was measured at $10 \mathrm{~cm}$ above the graft union and the trunk cross-sectional area (TCSA) was calculated. To estimate the percentages of branches of different length, the number of short ( $\leq 5 \mathrm{~cm}$ in length), middle (5-15 cm in length), and long ( $\geq 15$ $\mathrm{cm}$ in length) shoots were counted after natural leaf fall without any pruning (the pruning for all trees was made before budbreaks in each year). Fruit fresh weight and fruit number were recorded for each tree.

Statistical analysis. All data were analyzed without transformation using analysis of variance by SPSS 18.0 (SPSS Inc., Chicago, IL) and the graphics were produced in SigmaPlot 10.0 (Standford, CA).

\section{Results}

RLD-based fine root production and mortality. Based on overall RLDs, fine root production and mortality differed distinctly among standard and dwarfing rootstocks/ interstems. Both fine root production and fine root mortality were the largest in 'Red Fuji' trees growing on standard rootstock $\mathrm{BC}$ in all tested years, followed by trees of M.9 interstem and SH.40 interstem. In contrast, trees grafted directly on dwarfing rootstocks (M.9 and SH.40) produced the lowest RLD throughout the trial (Fig. 1).

Fine root production and mortality varied between fruit-bearing and nonbearing trees or years. In 2010, none of the trees flowered and set fruit, two distinct periods of active fine root production (March to July and July to October) were apparent in all rootstocks/ interstems, accompanied by hysteretic fine root mortality (April to August and August to November, respectively) (Fig. 1). In 2011, 'Red Fuji' trees growing on SH.40 began to bear fruit (Table 1), and their fine roots exhibited only a single peak of active production (March to June) followed by a single peak of fine root mortality (May to August). Trees on SH.40 interstem bear fruit in 2011, but it still showed two active peaks of root production and mortality. 'Red Fuji' trees on M.9 and BC rootstock and M.9 interstem did not bear fruit in 2011 and their fine root production and mortality showed the same pattern as in 2010 (Fig. 1). In 2012, there was no fruit set in trees grafted on BC and twopeak model of fine root production and mortality was observed, similar to that in 2010, whereas other four treatments, that is, trees on M.9 or SH.40 rootstocks and their interstems set fruit and active fine root production and mortality showed a single peak (April to July). When all trees fruited during
2013-15, fine root production and mortality showed a single peak pattern in all trees except M.9 in 2013 (Fig. 1; Table 1).

Analysis based on different soil depths showed that RLD-based fine root production and fine root mortality of 'Red Fuji' trees growing on $\mathrm{BC}$ were much higher than those on M.9 and SH.40 in all soil depths, except fine root production of $-100-\mathrm{cm}$ soil depth in 2012-15 (Fig. 2). However, fine root production and mortality of trees on SH.40 in $-150-\mathrm{cm}$ soil depth were apparently higher than those on M.9 after 2012, suggesting SH.40 is a deep-rooted rootstock compared with M.9. Fine root production and mortality of M.9 interstem and SH.40 interstem shared a similar pattern of soil-depth distribution as those directly on BC rootstock, but in most cases, their RLDs were relatively lower than trees growing on BC (Fig. 2).

$R N D$ - and $A R L$-based fine root production and mortality. RND- but not ARL-based fine root production and mortality varied remarkably between standard and dwarfing rootstocks/interstems. No apparent RND differences among rootstocks/interstems were detected in 2010-11 (Fig. 3). In 2012-15, however, RND of 'Red Fuji' trees growing on standard BC was far higher than that of trees grafted on dwarfing M.9 and SH.40. RND of trees growing on SH.40 interstem was close to but slightly lower than that of trees on BC, except in 2014 when its RNDs exceeded that of trees on BC (Fig. 3). RND of trees on M.9 interstem was typically intermediate between those directly on rootstock BC and M.9 except a smaller RND detected in 2013 (Fig. 3). No differences in ARL were observed among rootstocks/interstems in any tested years (Supplemental Fig. 1).

RND differed among rootstocks/interstems in different soil depths. RND of trees growing on M.9 was visibly higher than those growing on $\mathrm{BC}$ and $\mathrm{SH} .40$ rootstocks and those on M.9 interstem and SH.40 interstem in -20-cm soil during 2010-13, but not in 2014-15 (Fig. 4). No significant difference in RND in trees growing on $\mathrm{BC}$ was observed among soil depths during 2010-11, but in 2012 and onward, RND of trees on BC was apparently high in the deeper $-150-\mathrm{cm}$ soil. The RND of trees with M.9 as interstem showed a similar pattern to trees on $\mathrm{BC}$ rootstock, but in some case, its RND exceeded that of $\mathrm{BC}$, particularly during 2013-15 (Fig. 4). The RND of trees growing on SH.40 was distributed almost evenly across soil depths. The RND of trees growing on SH.40 interstem varied with years and soil depths, but was intermediate between trees on SH.40 and BC rootstocks (Fig. 4). Change in ARL in soil depth was negatively associated with RND. ARL of trees on M.9 was the lowest in the $-20-\mathrm{cm}$ soil because of its high RND during 2010-13 (Supplemental Fig. 2). No difference in ARL was observed among trees growing on BC, SH.40, and those with M.9 and SH.40 as interstems throughout the trial, except in trees on M.9 interstem in the -60 -cm soil in 2010 (Supplemental Fig. 2). 

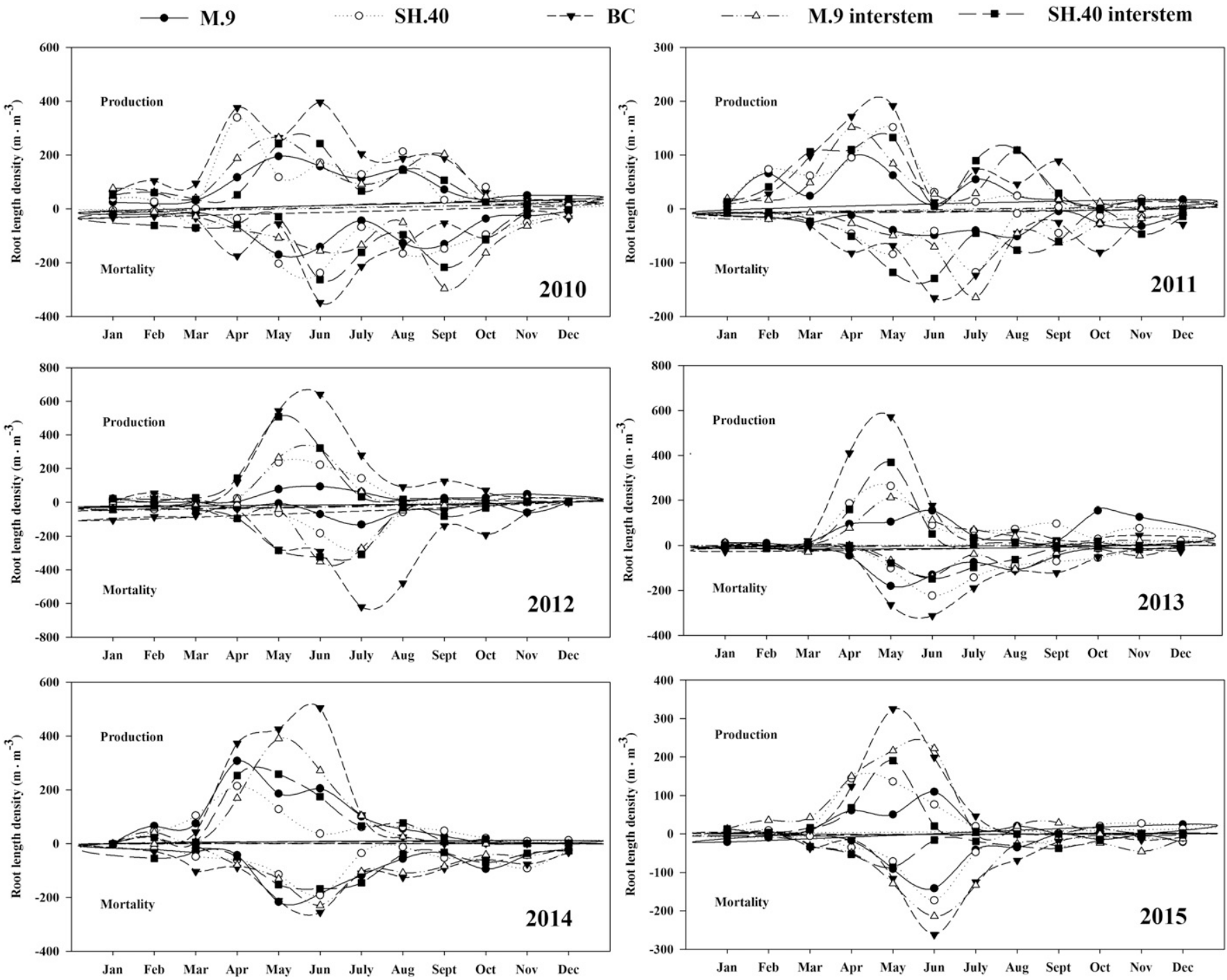

Fig. 1. Year round root length density (RLD)-based fine root production and mortality of 'Red Fuji' trees growing on three rootstocks [M.9, Shao series no. 40 (SH.40), and Baleng Crab (BC)] and two interstem combinations. M.9 interstem indicates M.9 was used as interstem of which the corresponding rootstock was $\mathrm{BC}$; the same as SH.40 interstem.

Table 1. Six-year fruit yield of 'Red Fuji' trees growing on three rootstocks (M.9, SH.40, and BC) and two interstem combinations. Trees were planted in 2009.

\begin{tabular}{lcccccc}
\hline & \multicolumn{7}{c}{ Avg fruit yield per tree $(\mathrm{kg})$} \\
\cline { 2 - 7 } Treatments & \multicolumn{1}{c}{2010} & \multicolumn{1}{c}{2011} & \multicolumn{1}{c}{2012} & \multicolumn{1}{c}{2013} & \multicolumn{1}{c}{2014} & 2015 \\
\hline M.9 & $0.00(0.0)$ & $0.00(0.0)$ & $0.64(6.0)$ & $7.01(30.0)$ & $1.29(6.0)$ & $2.30(11.5)$ \\
SH.40 & $0.00(0.0)$ & $0.42(3.5)$ & $2.01(11.0)$ & $4.81(20.5)$ & $2.61(12.0)$ & $3.69(19.0)$ \\
BC & $0.00(0.0)$ & $0.00(0.0)$ & $0.00(0.0)$ & $1.03(5.5)$ & $0.22(1.5)$ & $0.22(2.5)$ \\
M.9 interstem & $0.00(0.0)$ & $0.00(0.0)$ & $1.38(6.5)$ & $3.51(19.0)$ & $1.82(14.0)$ & $0.52(5.0)$ \\
SH.40 interstem & $0.00(0.0)$ & $1.89(11.0)$ & $2.30(11.0)$ & $11.81(122.0)$ & $0.15(1.5)$ & $7.62(47.5)$ \\
\hline
\end{tabular}

SH.40 = Shao series no. 40; BC = Baleng Crab.

Average fruit yield was sum of fresh weight per tree; values in parentheses were average fruit number per tree; M.9 interstem indicates M.9 was used as interstem of which the corresponding rootstock was BC; the same as SH.40 interstem.

Similar to RND, the overall total fine root number varied among rootstocks/interstems. During the entire trial, total fine root number was the highest (1236) in trees growing on $\mathrm{BC}$ and lowest in trees on M.9 interstem (619), then in trees on SH.40 (642) and M.9 (707). Compared with trees growing on $\mathrm{BC}$, the total fine root number was also substantially lower in trees with SH.40 as interstem (972) (Table 2).
The spatial distribution of fine roots varied with rootstocks/interstems but was not associated with dwarfing effect. First, the vertical distribution of fine roots differed among rootstocks. 'Red Fuji' trees growing on M.9 showed a shallow root system with about one-half of fine roots scattered within 0 - to $-20-\mathrm{cm}$ soil depth and $28.29 \%$ observed at -100 - to $-150-\mathrm{cm}$ soil depth (Table 2). Fine roots in standard rootstock, BC, exhibited almost uniform distribution at different soil depths, $23.41 \%$ of the fine roots in 0 - to $-20-\mathrm{cm}$ soil depths and up to $55.15 \%$ of them in the -100 - to $-150-\mathrm{cm}$ soil depths, indicating a deep root architecture (Table 2). Although SH.40 is classified as dwarfing rootstock, $44.08 \%$ of fine roots in trees grafted on SH.40 was produced in the 0 - to $-20-\mathrm{cm}$ soil depths but $37.38 \%$ was found in the -100 - to $-150-\mathrm{cm}$ soil depths, showing a pattern intermediate between M.9 and BC. There was no evidence that insertion of interstem pieces altered root architecture and both treatments with M.9 and SH.40 as interstems revealed a similar soil-depth distribution of fine roots to trees directly on $\mathrm{BC}$, although they did show a decrease in fine root number. Second, for all rootstocks/interstems, no apparent differences were detected in horizontal radial distribution of fine roots (Table 2).

Fine root diameters varied among rootstocks/interstems and soil depths. Regardless of vertical and horizontal distribution, mean 

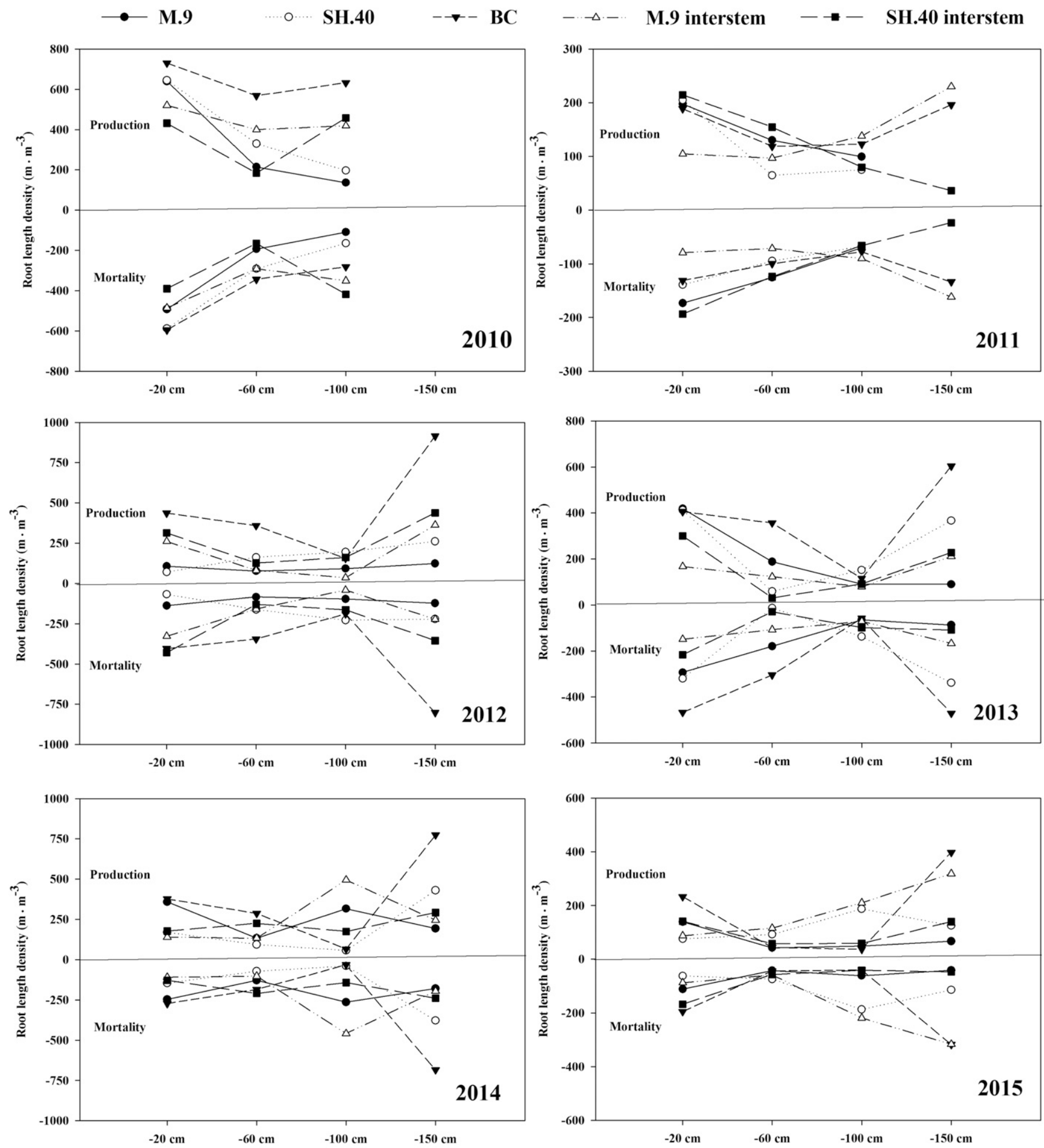

Fig. 2. Root length density-based fine root production and mortality by soil depth as fraction of 'Red Fuji' trees growing on three rootstocks [M.9, Shao series no. 40 (SH.40), and Baleng Crab (BC)] and two interstem combinations. M.9 interstem indicates M.9 was used as interstem of which the corresponding rootstock was BC; the same as SH.40 interstem.

root diameter of trees growing on $\mathrm{BC}$ was higher than that of trees on M.9 and SH.40, mean root diameter of both M.9 interstem and SH.40 as interstem was slightly lower than that of trees grafted directly on $\mathrm{BC}$, but higher than that of trees on dwarfing M.9 and SH.40, indicating mean root diameter was reduced by the dwarfing interstems (Table 2 ).
In summary, 'Red Fuji' trees growing on M.9 was characterized as a shallow but broad root architecture, in contrast, the root structure of 'Red Fuji' trees growing on BC was broad and deep, the root system of 'Red Fuji' trees growing on $\mathrm{SH} .40$ exhibited a relatively narrow but deep pattern. Fine root architectures of 'Red Fuji' trees with M.9 and SH.40 as interstems were similar to that of trees on $\mathrm{BC}$ but with lower numbers of fine roots.

Fine root longevity. The production of fine roots with different longevity varied among rootstocks/interstems. The overall RLD of 'Red Fuji' trees growing on BC in each longevity subgroup, especially the roots those that lived more than $81 \mathrm{~d}$, was higher 

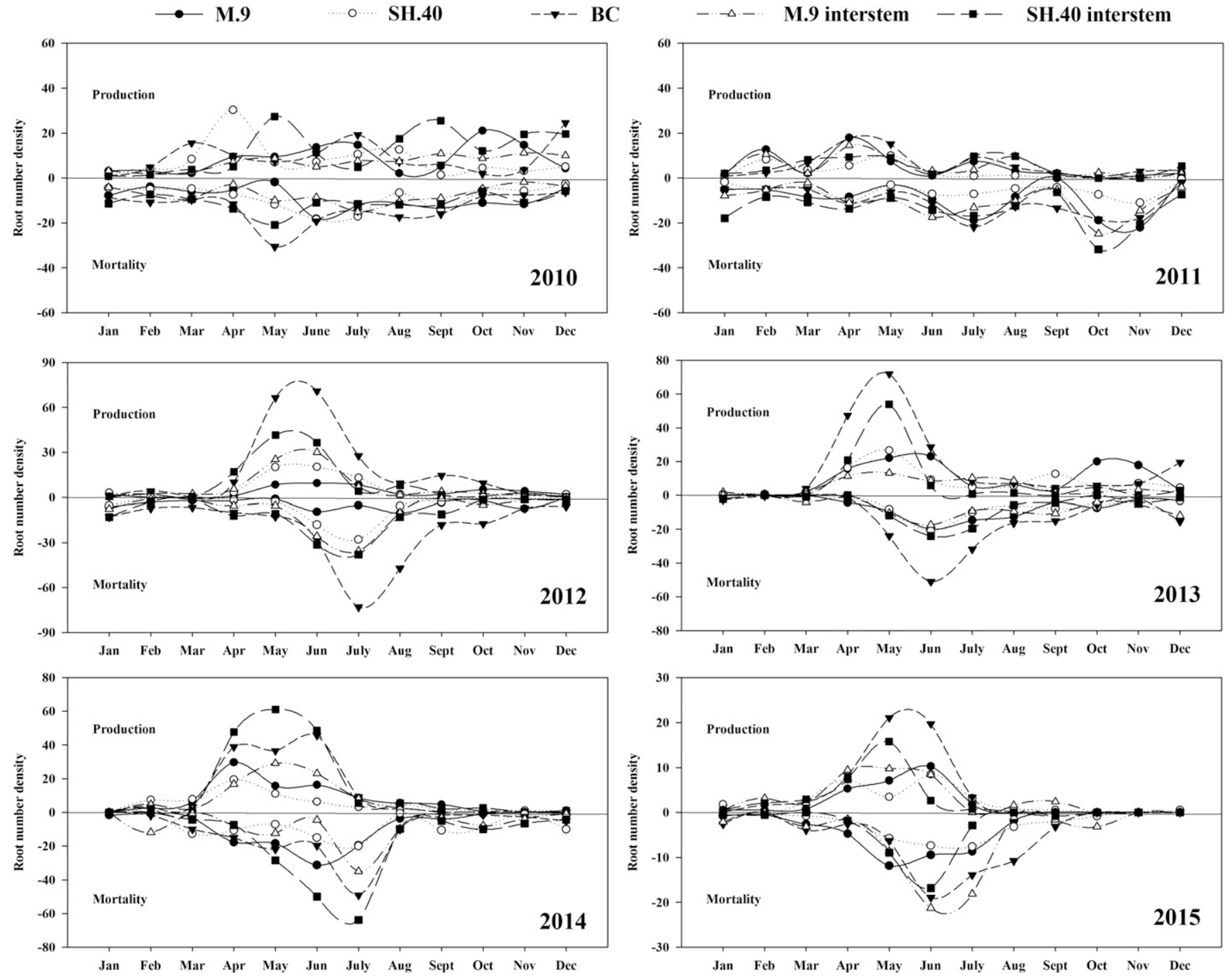

Fig. 3. Year round root number density of 'Red Fuji' trees growing on three rootstocks [M.9, Shao series no. 40 (SH.40), and Baleng Crab (BC)] and two interstem combinations. M.9 interstem indicates M.9 was used as interstem in which the corresponding rootstock was BC; the same as SH.40 interstem.

than those of trees on M.9 and SH.40 (Fig. 5A). RLDs of fine roots with $>81 \mathrm{~d}$ longevity in treatments with M.9 and SH.40 as interstems were also far higher than that in trees grafted on M.9 and SH.40, but were lower than that in trees on BC (Fig. 5A). The RLDs of fine roots that lived less than $80 \mathrm{~d}$ were relatively concentrated in spring and summer (Fig. 5B); however, the RLDs of fine roots with $>81 \mathrm{~d}$ life span was robustly produced almost all year round, despite a slight decrease in winter (Fig. 5C). For fine roots with both $<80$ and $>81 \mathrm{~d}$ life span, the RLD of trees growing on $\mathrm{BC}$ was the highest in all seasons (Fig. 5).

Tree growth and fruit yield. TCSA of trees growing on $\mathrm{BC}$ was about twice as large as those of trees growing on M.9 and SH.40 (Table 3). TCSA of trees with M.9 and SH.40 as interstem were significantly lower than that of trees on $\mathrm{BC}$ but relatively higher than that of trees on M.9 and SH.40 (Table 3). The percentage of short branches was as low as $8.00 \%$ in trees growing on $\mathrm{BC}$, compared with $11.64 \%$ to $52.72 \%$ in other four treatments (Table 3). Conversely, the percentage of long branches was $80.52 \%$ in trees growing on $\mathrm{BC}$ vs. $35.61 \%$ to $76.77 \%$ in the others (Table 3 ).

Cumulative yield for 6 -year trees growing on dwarfing M.9 and SH.40 was significantly higher than that of trees on $\mathrm{BC}$ (Table 3 ). Yield efficiency of trees growing on $\mathrm{BC}$ was only $0.06 \mathrm{~kg} \cdot \mathrm{cm}^{-2}$, whereas it was 1.16 and $1.08 \mathrm{~kg} \cdot \mathrm{cm}^{-2}$ in trees on M.9 and SH.40, respectively. Trees growing on SH.40 interstem showed similar yield efficiency to trees on SH.40. Yield efficiency of M.9 interstem was lower than that of M.9 but significantly higher than that of $\mathrm{BC}$ (Table 3). The average fruit size of trees growing on $\mathrm{BC}$ was the lowest $(96.55 \mathrm{~g})$, compared with 149.91$219.01 \mathrm{~g}$ in the other plants (Table 3).

The data showed that trees on dwarfing rootstocks/interstems possess a strong potential to control tree size, vegetative growth, and therefore to increase fruit productivity.

\section{Discussion}

Dwarfing rootstocks produce fewer fine roots than standard rootstocks, but the ARL of both dwarfing and standard rootstocks is quite similar. We previously reported that RLDs of 'Red Fuji' trees growing on M.9 and SH.40 were lower than those on BC in 2- to 3-year-old apple trees (Hou et al., 2012; Ma et al., 2013). High robustness was confirmed in this experiment using 6-year-old trees; not only the RLD-based fine root production and mortality but also the overall fine root number were distinctly lower in trees grafted on M.9 and SH.40 than in BC. The variation in RLDs could result from variation in either RNDs, ARL, or both. Data in Figs. 3 and 4 and Supplemental Figs. 1 and 2 showed that RND, not ARL, was the predominant contributor to RLD variation between standard and dwarfing rootstocks. The total fine root number was consistently far lower in trees growing on M.9 and SH.40 than in trees on $\mathrm{BC}$ (Table 2). Insertion of dwarfing interstem pieces also led to an intensive decrease in RLD, RND, as well as in the total fine root number, but not in ARL.

It is well established that apple trees on dwarfing rootstocks exhibit smaller canopy 

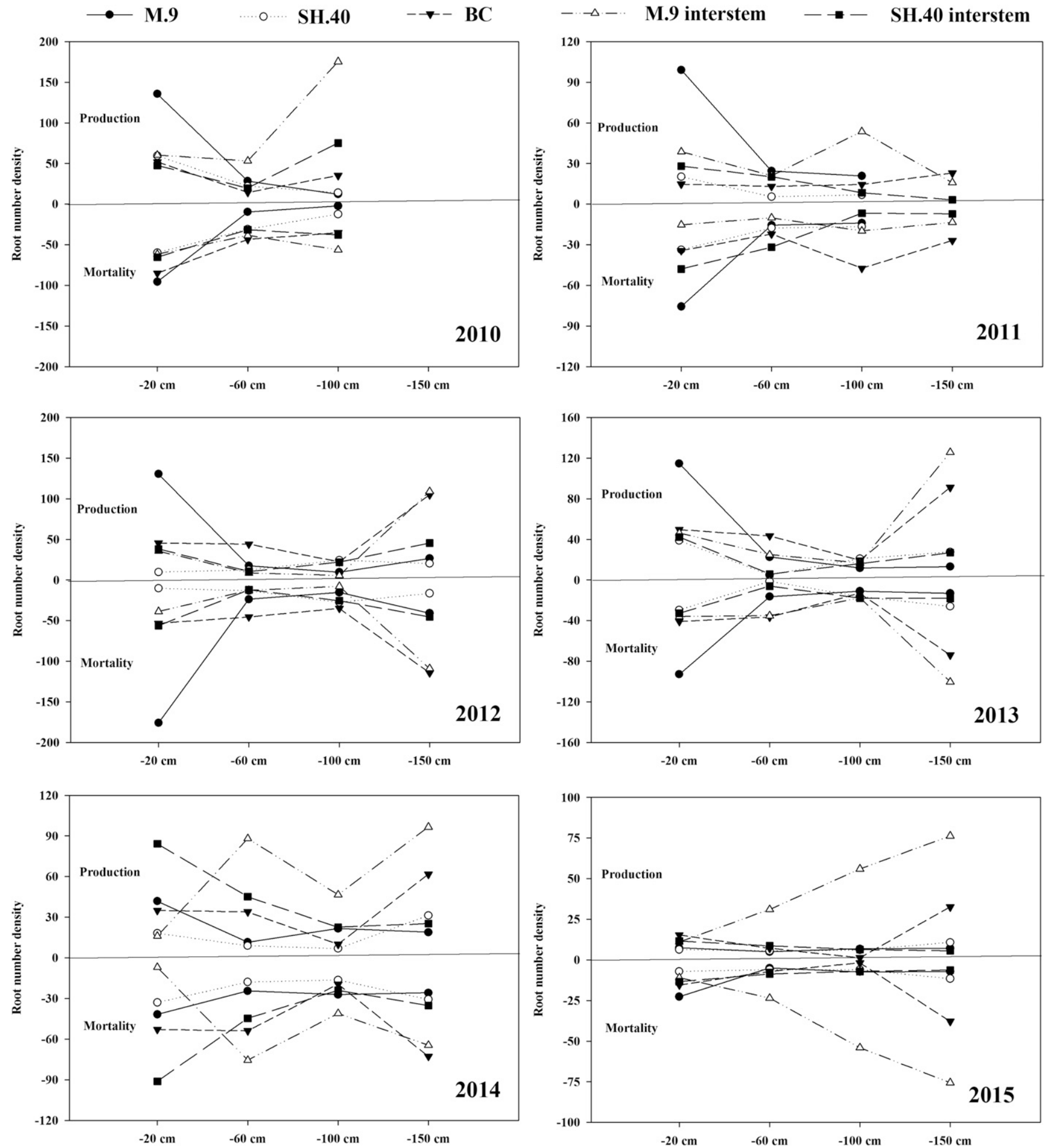

Fig. 4. Root number density by soil depth as fraction for 'Red Fuji' trees growing on three rootstocks [M.9, Shao series no. 40 (SH.40), and Baleng Crab (BC)] and two interstem combinations. M.9 interstem indicates M.9 was used as interstem of which the corresponding rootstock was BC; the same as SH.40 interstem.

size but produce higher fruit yield per area than those on standard rootstocks (Robinson et al., 1991; Samad et al., 1999; Webster, 1995). TCSA and percentages of short branches were significantly lower in trees growing on M.9 and SH.40 but the total yield and average fruit weight were very high (Table 3). However, to date, it remains unclear whether lower RLDs in dwarfing rootstocks were the cause or effect of dwarfing (Beakbane, 2008; Song et al., 2016). Weakened root zeatin biosynthetic activity in M.9 has been proposed as the initial mechanism of the dwarfing effect (Li et al., 2012; Zhang et al., 2015). It has been speculated that the lower quantity of fine roots in dwarfing rootstocks may weaken vegetative growth in the tree trunk and the canopy
(Czynczyk et al., 2006; Hirst and Ferree, 1995; Schechter et al., 1991). The consequent domino effect would allow relatively larger proportions of assimilates to be redistributed to fruit and result in higher yield in apple trees on dwarfing rootstocks (Fallahi et al., 2001, 2002; Preston, 1970). In most plant species, the initiation and the elongation of fine roots are precisely regulated via independent 
Table 2. Fine root spatial distribution of 'Red Fuji' trees growing on three rootstocks (M.9, SH.40, and BC) and two interstem combinations.

\begin{tabular}{|c|c|c|c|c|c|c|c|c|}
\hline Treatments & $\begin{array}{c}\text { Vertical } \\
\operatorname{depth}^{\mathrm{z}}(\mathrm{cm})\end{array}$ & $\begin{array}{l}\text { No. of } \\
\text { roots }^{x}\end{array}$ & $\begin{array}{l}\text { Proportion of } \\
\text { total roots }(\%)\end{array}$ & $\begin{array}{l}\text { Mean diam } \\
\left( \pm \mathrm{SE},{ }^{\mathrm{w}} \mathrm{mm}\right)\end{array}$ & $\begin{array}{c}\text { Horizontal } \\
\text { distance }^{\mathrm{y}}(\mathrm{cm})\end{array}$ & No. of roots & $\begin{array}{l}\text { Proportion of } \\
\text { total roots }(\%)\end{array}$ & $\begin{array}{l}\text { Mean diam } \\
\left( \pm \mathrm{SE},{ }^{\mathrm{w}} \mathrm{mm}\right)\end{array}$ \\
\hline \multirow{3}{*}{ M.9 } & -60 & 153 & 21.64 & $0.28 \pm 0.014$ & 18.75 & 189 & 26.73 & $0.24 \pm 0.015$ \\
\hline & -100 & 94 & 13.30 & $0.27 \pm 0.016$ & -56.25 & 199 & 28.15 & $0.25 \pm 0.015$ \\
\hline & Total & 707 & 100 & & Total & 707 & 100 & \\
\hline \multirow[t]{3}{*}{ SH.40 } & -20 & 283 & 44.08 & $0.24 \pm 0.007$ & -18.75 & 162 & 25.23 & $0.25 \pm 0.014$ \\
\hline & -60 & 119 & 18.54 & $0.27 \pm 0.014$ & 18.75 & 189 & 29.44 & $0.21 \pm 0.011$ \\
\hline & Total & 642 & 100 & & Total & 642 & 100 & \\
\hline \multirow[t]{5}{*}{$\mathrm{BC}$} & -20 & 361 & 23.41 & $0.36 \pm 0.011$ & -18.75 & 242 & 19.58 & $0.28 \pm 0.018$ \\
\hline & -60 & 282 & 21.44 & $0.39 \pm 0.015$ & 18.75 & 333 & 26.94 & $0.37 \pm 0.017$ \\
\hline & -100 & 180 & 23.73 & $0.30 \pm 0.014$ & -56.25 & 345 & 27.91 & $0.38 \pm 0.022$ \\
\hline & -150 & 413 & 31.42 & $0.37 \pm 0.011$ & 56.25 & 316 & 25.57 & $0.38 \pm 0.024$ \\
\hline & Total & 1236 & 100 & & Total & 1,236 & 100 & \\
\hline M.9 interstem & -20 & 169 & 27.30 & $0.30 \pm 0.010$ & -18.75 & 194 & 31.34 & $0.32 \pm 0.018$ \\
\hline \multirow{4}{*}{ SH.40 interstem } & -60 & 197 & 20.27 & $0.36 \pm 0.015$ & 18.75 & 161 & 16.56 & $0.37 \pm 0.022$ \\
\hline & -100 & 215 & 22.12 & $0.28 \pm 0.009$ & -56.25 & 256 & 26.34 & $0.33 \pm 0.015$ \\
\hline & -150 & 109 & 11.21 & $0.37 \pm 0.014$ & 56.25 & 283 & 29.12 & $0.36 \pm 0.015$ \\
\hline & Total & 972 & 100 & & Total & 972 & 100 & \\
\hline
\end{tabular}

SH.40 = Shao series no. $40 ; \mathrm{BC}=$ Baleng Crab.

${ }^{\mathrm{z}}$ Vertical depth was distance between minirhizotron tube and soil surface.

${ }^{\mathrm{y}}$ Horizontal distance was distance between minirhizotron tube and apple tree trunk.

${ }^{\mathrm{x}}$ Number of roots was the accumulation over 6 years.

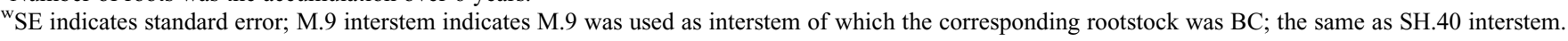

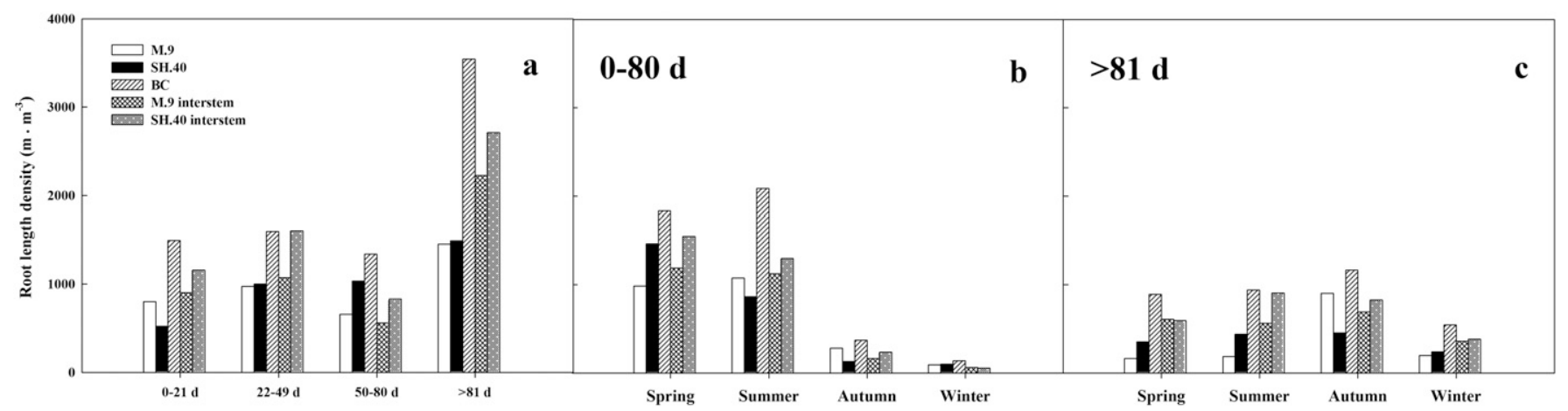

Fig. 5. Distribution and seasonal root length density (RLD) changes of roots with different longevities in 'Red Fuji' trees growing on three rootstocks [M.9, Shao series no. 40 (SH.40), and Baleng Crab (BC)] and two interstem combinations. (A) Distribution of fine root longevity; (B) seasonal RLD changes of roots with 0-80 d longevity; and (C) seasonal RLD changes of roots with $>80 \mathrm{~d}$ longevity. M.9 interstem indicates M.9 was used as interstem of which the corresponding rootstock was BC; the same as SH.40 interstem. Spring was from March to May, Summer was from June to August, Autumn was from September to November, and Winter was from December to February of the next year.

physiological mechanisms (Benkova and Hejatko, 2009; Fukaki and Tasaka, 2009): the initiation of fine roots is triggered by the asymmetrical distribution of auxin in pericycle cells (Casimiro et al., 2001; Marhavy et al., 2013) and cytokinin inhibits fine root initiation but stimulates fine root elongation (Bishopp et al., 2011; Debi et al., 2005). In total, fewer fine roots were detected in dwarfing rootstocks in this study, but their average length was not shorter than that in nondwarfing rootstocks. This is contrary to the abovementioned hypothesis and is important for future investigations on dwarfing mechanism of rootstocks.

Root architecture whatever deep or shallow is not associated with dwarfing habit. A majority of standard or seedling rootstocks exhibited a deep root development (Manschadi et al., 2008). Most East Malling apple dwarfing rootstocks or their descendants have shown excellent capacity for apple tree size control under various ambient environments (Samad et al., 1999; Seleznyova et al., 2008; Webster, 1995). On the other hand, they produce shallow root architecture leading to some disadvantages such as weak anchorage in the soil and lower stress tolerance (Artacho and Bonomelli, 2016; Vaio et al., 2009).

SH.40 is considered to be a dwarfing rootstock (Shao et al., 1988, 1991). However, we found that up to $37.38 \%$ of the fine roots in 'Red Fuji' trees growing on SH.40 were distributed at -100 - to $-150-\mathrm{cm}$ soil depth (Table 2). In addition, trees on SH.40 showed greater RLD- or RND-based fine root production and mortality in deep soil depth over several years and thus a deep root architecture by comparison with M.9 (Figs. 2 and 4). Both RLD- and RND-based fine root production and mortality were lower in trees with M.9 and SH.40 as interstem than in trees on BC (Fig. 1), although their soil-depth distribution patterns were about the same as BC (Table 2). This is consistent with our previous results that insertion of dwarfing interstem pieces may cause a decline in fine root production, but does not alter soil-depth distribution of fine roots (Ma et al., 2013). Generally, rooting depth has been found to be 
Table 3. Tree growth and fruit yield of 'Red Fuji' trees growing on three rootstocks (M.9, SH.40, and BC) and two interstem combinations in 2015.

\begin{tabular}{|c|c|c|c|c|c|c|c|}
\hline \multirow[b]{2}{*}{ Treatments } & \multirow[b]{2}{*}{$\operatorname{TCSA}\left(\mathrm{cm}^{2}\right)$} & \multicolumn{3}{|c|}{ Branches $(\%)$} & \multirow{2}{*}{$\begin{array}{l}\text { Cumulative yield, } \\
2011-15(\mathrm{~kg})^{\mathrm{z}}\end{array}$} & \multirow{2}{*}{$\begin{array}{l}\text { Yield efficiency } \\
\left(\mathrm{kg} \cdot \mathrm{cm}^{-2} \mathrm{TCSA}\right)^{\mathrm{y}}\end{array}$} & \multirow[b]{2}{*}{ Avg fruit size $(g)$} \\
\hline & & Short $(\leq 5 \mathrm{~cm})$ & Middle $(5-15 \mathrm{~cm})$ & Long $(\geq 15 \mathrm{~cm})$ & & & \\
\hline$\overline{\text { M.9 }}$ & $19.31 \mathrm{~d}$ & $14.07 \mathrm{~b}$ & $9.17 \mathrm{a}$ & $76.76 \mathrm{a}$ & $22.46 \mathrm{~b}$ & $1.16 \mathrm{a}$ & $219.01 \mathrm{a}$ \\
\hline SH.40 & $25.11 \mathrm{c}$ & $40.16 \mathrm{a}$ & $10.10 \mathrm{a}$ & $49.74 b$ & $27.08 \mathrm{~b}$ & $1.08 \mathrm{a}$ & $196.10 \mathrm{~b}$ \\
\hline $\mathrm{BC}$ & $49.75 \mathrm{a}$ & $8.00 \mathrm{~b}$ & $11.47 \mathrm{a}$ & $80.52 \mathrm{a}$ & $2.94 \mathrm{~d}$ & $0.06 \mathrm{c}$ & $96.55 \mathrm{e}$ \\
\hline M.9 interstem & $31.33 \mathrm{~b}$ & $11.64 \mathrm{~b}$ & $13.26 \mathrm{a}$ & $75.10 \mathrm{a}$ & $14.47 \mathrm{c}$ & $0.46 \mathrm{~b}$ & $149.91 \mathrm{~d}$ \\
\hline SH.40 interstem & $34.56 \mathrm{~b}$ & $52.72 \mathrm{a}$ & $11.67 \mathrm{a}$ & $35.61 \mathrm{~b}$ & $47.55 \mathrm{a}$ & $1.38 \mathrm{a}$ & $165.62 \mathrm{~cd}$ \\
\hline
\end{tabular}

SH.40 = Shao series no. 40; BC = Baleng Crab; TCSA $=$ trunk cross-sectional area.

${ }^{\mathrm{z}}$ Cumulative yield was the sum of fruit yield from 2011 to 2015.

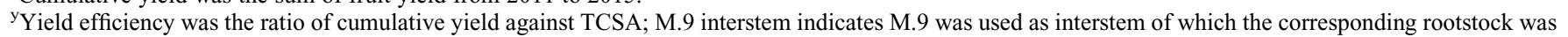
$\mathrm{BC}$; the same as SH.40 interstem; the letters in the same column indicate the significance at 0.05 level.

mainly associated with root growth angle, maximum root length, and gravitropism (Ali et al., 2015; Sato et al., 2015; Trachsel et al., 2013). The asymmetrical growth in cell elongation zone causes root downward bending in response to gravity (Uga et al., 2013). The balance of endogenous hormones plays important roles in dwarfing effect of M.9 rootstocks. For example, lower isopentenyl transferase gene expression in roots of M.9 resulted first in a limited zeatin synthesis capacity in M.9 roots ( $\mathrm{Li}$ et al., 2012), then induced zeatin deficiency in aerial parts, and finally suppressed vegetative growth (Zhang et al., 2015). Further investigation is required to clarify the relationship between dwarfing and rooting traits in apple rootstocks, to develop the potential for efficient selection of deep-rooted dwarfing rootstocks.

Dwarfing rootstocks usually have smaller diameter but similar life span with standard rootstocks. Fine root life span usually significantly increases with fine root diameter (McCormack et al., 2012). Dwarfing M.9 and SH.40 with smaller diameter had shorter life span than standard BC (Hou et al., 2012). The present work also revealed a smaller mean root diameter in trees growing on M.9 and SH.40 than those on BC (Table 2). RLDs of fine roots with life span above $81 \mathrm{~d}$ in trees growing on $\mathrm{BC}$ were the only ones higher than those in trees grafted on M.9 and SH.40 (Fig. 5A), thus the larger proportion of roots with longer life span may contribute to the longevity of fine roots in BC. Fine roots with life span $<80 \mathrm{~d}$ occurred largely in spring and summer, but numbers of fine roots living more than $81 \mathrm{~d}$ were consistent year round (Fig. 5B and C). We speculated that the roots with less than an 80-d life span were most likely to be absorptive roots, whereas those that lived for more than $81 \mathrm{~d}$ may function as anchoring roots, based on a category of diameter-related dimension (Kong et al., 2014, 2015). However, the relationship between life span and the absorptive/anchoring function of fine roots needs further study.

Fine root production and mortality patterns differed between fruit-bearing and nonbearing trees. Though it is accepted that fruit trees typically have a bimodal pattern of root production, the periodicity of root growth would be expected to differ due to the adverse effect of fruiting (Atkinson, 1980; Eissenstat et al., 2006) or different plant ages (Baddeley and Watson, 2005; Psarras et al., 2000). One peak of root growth was observed in fruiting and two in nonfruiting trees (Head, 1969). By analyzing total RLDs, only one root growth peak was observed in 2-year-old nonbearing 'Red Fuji' trees growing on $\mathrm{BC}$ and M.9, but two in nonbearing trees on SH.40 (Ma et al., 2013). A main peak of new root emergences coincided partially with a major phase of shoot and fruit growth and another smaller peak was recorded by Psarras et al. (2000), they also found that adult trees had only one peak of fine root production, whereas young trees did not have obvious fine root flushes. However, we found two active fine root production and mortality periods before bearing fruit, otherwise plants showed unimodal growth after fruit bearing (Fig. 1). This might be attributed to the fact that fruiting can reduce root growth (Ben Mimoun and DeJong, 2006; Morinaga et al., 2003), but the relationship between fruit growth and belowground fine root occurrence is still unclear. An exception in this experiment was that an extra peak of fine root production was seen in trees growing on M.9 during October to November (Fig. 1; Table 1). This was most probably caused by the fact that seven rhizotron tubes in one rhizo-pit of trees growing on M.9 were slightly distorted due to natural soil sedimentation and were replaced with new tubes in Sept. 2013. Soil disturbance by newly installed minirhizotron tubes always results in higher fine root production (Johnson et al., 2001; Wells et al., 2002).

\section{Conclusion}

RND- and thus RLD-based fine root production and mortality as well as the overall fine root number of dwarfing rootstocks were markedly lower than that of standard rootstock. Insertion of dwarfing interstems reduced fine root production and mortality. ARL and soil-depth distribution did not differ between dwarfing and standard rootstocks. Our data confirm that dwarfing rootstocks possess excellent potential to control vegetative growth and tree size and increase fruit production and are therefore of great potential interest to the horticultural industry.

\section{Literature Cited}

Ahmadi, S.H., A.R. Sepaskhah, M.N. Andersen, F. Plauborg, C.R. Jensen, and S. Hansen. 2014. Modeling root length density of field grown potatoes under different irrigation strategies and soil textures using artificial neural networks. Field Crops Res. 162:99-107.
Ahrens, B., K. Hansson, E.F. Solly, and M. Schrumpf. 2014. Reconcilable differences: A joint calibration of fine-root turnover times with radiocarbon and minirhizotrons. New Phytol. 204:932-942.

Ali, M.L., J. Luetchens, J. Nascimento, T.M Shaver, G.R. Kruger, and A.J. Lorenz. 2015. Genetic variation in seminal and nodal root angle and their association with grain yield of maize under water-stressed field conditions. Plant Soil 397:213-225.

Anderson, L.J., L.H. Comas, A.N. Lakso, and D.M Eissenstat. 2003. Multiple risk factors in root survivorship: A 4-year study in Concord grape. New Phytol. 158:489-501.

Artacho, P. and C. Bonomelli. 2016. Changes in fine-root production, phenology and spatial distribution in response to $\mathrm{N}$ application in irrigated sweet cherry trees. Tree Physiol. 36:601-617.

Atkinson, D. 1980. The distribution and effectiveness of the roots of tree crops. Hort. Rev. 2:424-490.

Baddeley, J.A. and C.A. Watson. 2005. Influences of root diameter, tree age, soil depth and season on fine root survivorship in Prunus avium. Plant Soil 276:15-22.

Basile, B., D.R. Bryla, M.L. Salsman, J. Marsal, C. Cirillo, R.S. Johnson, and T.M. Dejong. 2007. Growth patterns and morphology of fine roots of size-controlling and invigorating peach rootstocks. Tree Physiol. 27:231-241.

Beakbane, A.B. 2008. Possible mechanisms of rootstock efffect. Ann. Appl. Biol. 44:517-521.

Ben Mimoun, M. and T.M. DeJong. 2006. Effect of fruit crop load on peach root growth. Acta Hort. 713:169-175.

Benkova, E. and J. Hejatko. 2009. Hormone interactions at the root apical meristem. Plant Mol. Biol. 69:383-396.

Bianco, R.L., M. Policarpo, and L. Scariano. 2003. Effects of rootstock vigour and in-row spacing on stem and root growth, conformation and dry-matter distribution of young apple trees. J. Hort. Sci. Biotechnol. 78:828-836.

Bishopp, A., E. Benkova, and Y. Helariutta. 2011. Sending mixed messages: Auxin-cytokinin crosstalk in roots. Curr. Opin. Plant Biol. 14:10-16.

Black, B.L., D. Drost, T. Lindstrom, J. Reeve, J. Gunnell, and G.L. Reighard. 2010. A comparison of root distribution patterns among Prunus rootstocks. J. Amer. Pomol. Soc. 64:52-60.

Burton, A.J., K.S. Pregitzer, and R.L. Hendrick. 2000. Relationships between fine root dynamics and nitrogen availability in Michigan northern hardwood forests. Oecologia 125:389-399.

Casimiro, I., A. Marchant, R.P. Bhalerao, T. Beeckman, S. Dhooge, R. Swarup, N. Graham, D. Inze, G. Sandberg, P.J. Casero, and M. Bennett. 2001. Auxin transport promotes Arabidopsis lateral root initiation. Plant Cell 13:843-852.

Czynczyk, A., P. Bielicki, and B. Bartosiewicz. 2006. Growth and yielding of 'Jonagold' and 
'Ligol' apple trees on M.9 and P22 subclones, and some other Polish rootstocks. Sodininkyste Ir Daržininkystè 173-180.

De Silva, H.N., A.J. Hall, D.S. Tustin, and P.W Gandar. 1999. Analysis of distribution of root length density of apple trees on different dwarfing rootstocks. Ann. Bot. (Lond.) 83:335-345.

Debi, B.R., S. Taketa, and M. Ichii. 2005. Cytokinin inhibits lateral root initiation but stimulates lateral root elongation in rice (Oryza sativa). J. Plant Physiol. 162:507-515.

Eissenstat, D.M., T.L. Bauerle, L.H. Comas, A.N. Lakso, D. Neilsen, G.H. Neilsen, and D.R. Smart. 2006. Seasonal patterns of root growth in relation to shoot phenology in grape and apple. Acta Hort. 721:21-26.

Fallahi, E., I.J. Chun, G.H. Neilsen, and W.M. Colt. 2001. Effects of three rootstocks on photosynthesis, leaf mineral nutrition, and vegetative growth of "BC-2 Fuji" apple trees. J. Plant Nutr. 24:827-834.

Fallahi, E., W.M. Colt, B. Fallahi, and I.J. Chun. 2002. The importance of apple rootstocks on tree growth, yield, fruit quality, leaf nutrition, and photosynthesis with an emphasis on 'Fuji'. HortTechnology 12:38-44.

Fukaki, H. and M. Tasaka. 2009. Hormone interactions during lateral root formation. Plant Mol. Biol. 69:437-449.

Fukuzawa, K., H. Shibata, K. Takagi, F. Satoh, T. Koike, and K. Sasa. 2013. Temporal variation in fine-root biomass, production and mortality in a cool temperate forest covered with dense understory vegetation in northern Japan. For. Ecol. Mgt. 310:700-710.

Garcia-Villanueva, E., E. Costes, and C. Jourdan. 2004. Comparing root and aerial growth dynamics of two apple hybrids ownrooted and grafted on M.9. Acta Hort. 658:61-67.

Gaul, D., D. Hertel, and C. Leuschner. 2009. Estimating fine root longevity in a temperate Norway spruce forest using three independent methods. Funct. Plant Biol. 36:11-19.

Germon, A., R. Cardinael, I. Prieto, Z. Mao, J. Kim, A. Stokes, C. Dupraz, J.P. Laclau, and C. Jourdan. 2016. Unexpected phenology and lifespan of shallow and deep fine roots of walnut trees grown in a silvoarable Mediterranean agroforestry system. Plant Soil 401:409426.

Head, G.C. 1969. The effects of fruiting and defoliation on seasonal trends in new root production on apple trees. J. Hort. Sci. 44:175-181.

Hirst, P.M. and D.C. Ferree. 1995. Rootstock effects on shoot morphology and spur quality of 'Delicious' apple and relationships with precocity and productivity. J. Amer. Soc. Hort. Sci. 120:622-634.

Hou, C., L. Ma, F. Luo, Y. Wang, X. Zhang, and Z. Han. 2012. Impact of rootstock and interstems on fine root survivorship and seasonal variation in apple. Sci. Hort. 148:169-176.

Hulugalle, N.R., K.J. Broughton, and D.K.Y. Tan. 2015. Fine root production and mortality in irrigated cotton, maize and sorghum sown in vertisols of northern New South Wales, Australia. Soil Tillage Res. 146:313-322.

Johnson, M.G., D.T. Tingey, D.L. Phillips, and M.J. Storm. 2001. Advancing fine root research with minirhizotrons. Environ. Exp. Bot. 45:263-289.

Kong, D., C. Ma, Q. Zhang, L. Li, X. Chen, H. Zeng, and D. Guo. 2014. Leading dimensions in absorptive root trait variation across 96 subtropical forest species. New Phytol. 203:863-872.
Kong, D., J. Wang, P. Kardol, H. Wu, H. Zeng, X. Deng, and Y. Deng. 2015. The root economics spectrum: Divergence of absorptive root strategies with root diameter. Biogeosciences Discuss. 12:13041-13067.

Laiho, R., R. Bhuiyan, P. Strakova, P. Makiranta, T. Badorek, and T. Penttila. 2014. Modified ingrowth core method plus infrared calibration models for estimating fine root production in peatlands. Plant Soil 385:311-327.

Li, H.L., H. Zhang, C. Yu, L. Ma, Y. Wang, X.Z. Zhang, and Z.H. Han. 2012. Possible roles of auxin and zeatin for initiating the dwarfing effect of M9 used as apple rootstock or interstock. Acta Physiol. Plant. 34:235-244.

Liedgens, M. and W. Richner. 2001. Minirhizotron observations of the spatial distribution of the maize root system. Agron. J. 93:1097-1104.

Ma, L., C.W. Hou, X.Z. Zhang, H.L. Li, D.G. Han, Y. Wang, and Z.H. Han. 2013. Seasonal growth and spatial distribution of apple tree roots on different rootstocks or interstems. J. Amer. Soc. Hort. Sci. 138:79-87.

Majdi, H. 1996. Root sampling methods: Applications and limitations of the minirhizotron technique. Plant Soil 185:255-258.

Majdi, H. and P. Andersson. 2005. Fine root production and turnover in a Norway spruce stand in northern Sweden: Effects of nitrogen and water manipulation. Ecosystems (N. Y.) 8:191199.

Majdi, H., K. Pregitzer, A.S. Moren, J.E. Nylund, and G.I. Agren. 2005. Measuring fine root turnover in forest ecosystems. Plant Soil 276:1-8.

Makita, N., Y. Hirano, M. Dannoura, Y. Kominami, T. Mizoguchi, H. Ishii, and Y. Kanazawa. 2009. Fine root morphological traits determine variation in root respiration of Quercus serrata. Tree Physiol. 29:579-585.

Makkonen, K. and H.S. Helmisaari. 2001. Fine root biomass and production in Scots pine stands in relation to stand age. Tree Physiol. 21:193198.

Manschadi, A.M., G.L. Hammer, J.T. Christopher, and P. deVoil. 2008. Genotypic variation in seedling root architectural traits and implications for drought adaptation in wheat (Triticum aestivum L.). Plant Soil 303:115-129.

Marhavy, P., M. Vanstraelen, B. De Rybel, Z.J. Ding, M.J. Bennett, T. Beeckman, and E. Benkova. 2013. Auxin reflux between the endodermis and pericycle promotes lateral root initiation. EMBO J. 32:149-158.

Marsal, J., B. Basile, L. Solari, and T.M. DeJong. 2003. Influence of branch autonomy on fruit, scaffold, trunk and root growth during Stage III of peach fruit development. Tree Physiol. 23:313-323.

McCormack, M.L., T.S. Adams, E.A.H. Smithwick, and D.M. Eissenstat. 2012. Predicting fine root lifespan from plant functional traits in temperate trees. New Phytol. 195:823-831.

Morinaga, K., S. Imai, H. Yakushiji, and Y. Koshita. 2003. Effects of fruit load on partitioning of $\mathrm{N}-15$ and $\mathrm{C}-13$, respiration, and growth of grapevine roots at different fruit stages. Sci. Hort. 97:239-253.

Noguchi, K., T. Sakata, T. Mizoguchi, and M. Takahashi. 2004. Estimation of the fine root biomass in a Japanese cedar (Cryptomeria japonica) plantation using minirhizotrons. J. For. Res. 9:261-264.

Noguchi, K., T. Sakata, T. Mizoguchi, and M. Takahashi. 2005. Estimating the production and mortality of fine roots in a Japanese cedar (Cryptomeria japonica D. Don) plantation using a minirhizotron technique. J. For. Res. 10:435-441.
Olesinski, J., M.B. Lavigne, J.A. Jr Kershaw, and M.J. Krasowski. 2012. Fine-root dynamics change during stand development and in response to thinning in balsam fir (Abies balsamea L. Mill.) forests. For. Ecol. Mgt. 286:48-58

Pateña, G. and K.T. Ingram. 2000. Digital acquisition and measurement of peanut root minirhizotron images. Agron. J. 92:541-544.

Preston, A.P. 1970. Apple rootstock studies: Growth and cropping of trees on M.26, M. VII, and M.II. Annual Report East Malling Research Station.

Psarras, G., I.A. Merwin, A.N. Lakso, and J.A. Ray. 2000. Root growth phenology, root longevity, and rhizosphere respiration of field grown 'Mutsu' apple trees on 'Malling 9' rootstock. J. Amer. Soc. Hort. Sci. 125:596602.

Robinson, T.L., A.N. Lakso, and S.G. Carpenter. 1991. Canopy development, yield, and fruit quality of 'Empire' and 'Delicious' apple trees grown in four orchard production systems for ten years. J. Amer. Soc. Hort. Sci. 116:179187.

Rosecrance, R.C., S.A. Weinbaum, and P.H. Brown. 1996. Assessment of nitrogen, phosphorus, and potassium uptake capacity and root growth in mature alternate-bearing pistachio (Pistacia vera) trees. Tree Physiol. 16:949956.

Samad, A., D.L. McNeil, and Z.U. Khan. 1999. Effect of interstock bridge grafting (M9 dwarfing rootstock and same cultivar cutting) on vegetative growth, reproductive growth and carbohydrate composition of mature apple trees. Sci. Hort. 79:23-38.

Sato, E.M., H. Hijazi, M.J. Bennett, K. Vissenberg, and R. Swarup. 2015. New insights into root gravitropic signalling. J. Expt. Bot. 66:21552165 .

Satomura, T., K. Fukuzawa, and T. Horikoshi. 2007. Considerations in the study of tree fineroot turnover with minirhizotrons. Plant Root 1:34-45.

Schechter, I., D.C. Elfving, and J.T.A. Proctor. 1991. Rootstock affects vegetative growth characteristics and productivity of 'Delicious' apple. HortScience 26:1145-1148.

Seleznyova, A.N., D.S. Tustin, and T.G. Thorp. 2008. Apple dwarfing rootstocks and interstocks affect the type of growth units produced during the annual growth cycle: Precocious transition to flowering affects the composition and vigour of annual shoots. Ann. Bot. (Lond.) 101:679-687.

Shao, K.J., D.K. Li, and Z.R. Zhang. 1988. A study on the breeding of apple dwarfing rootstock SH series (in Chinese). Acta Agr. Boreali. Sinica 3:86-93.

Shao, K.J., D.K. Li, Z.R. Zhang, and X.M. Gao. 1991. A study on the characters and physiological traits of $\mathrm{SH}$ series apples dwarf stocks (in Chinese). Acta Hort. Sinica 18:289-295.

Song, C.H., D. Zhang, J. Zhang, L.W. Zheng, C.P. Zhao, J.J. Ma, N. An, and M.Y. Han. 2016. Expression analysis of key auxin synthesis, transport, and metabolism genes in different young dwarfing apple trees. Acta Physiol. Plant. 38:43.

Trachsel, S., S.M. Kaeppler, K.M. Brown, and J.P. Lynch. 2013. Maize root growth angles become steeper under low $\mathrm{N}$ conditions. Field Crops Res. 140:18-31.

Uga, Y., K. Sugimoto, S. Ogawa, J. Rane, M. Ishitani, N. Hara, Y. Kitomi, Y. Inukai, K. Ono, N. Kanno, H. Inoue, H. Takehisa, R. Motoyama, 
Y. Nagamura, J.Z. Wu, T. Matsumoto, T. Takai, K. Okuno, and M. Yano. 2013. Control of root system architecture by DEEPER ROOTING 1 increases rice yield under drought conditions. Nat. Genet. 45:1097-1102.

Vaio, C.D., C. Cirillo, M. Buccheri, and F. Limongelli. 2009. Effect of interstock (M.9 and M.27) on vegetative growth and yield of apple trees (cv "Annurca"). Sci. Hort. 119:270-274.

Webster, A.D. 1995. Rootstock and interstock effects on deciduous fruit tree vigour, precocity, and yield productivity. N. Z. J. Crop Hort. Sci. 23:373-382.

Wells, C.E., D.M. Glenn, and D.M. Eissenstat. 2002. Changes in the risk of fine-root mortality with age: A case study in peach, Prunus persica (Rosaceae). Amer. J. Bot. 89:79-87.

Withington, J.M., P.B. Reich, J. Oleksyn, and D.M. Eissenstat. 2006. Comparisons of structure and life span in roots and leaves among temperate trees. Ecol. Monogr. 76:381-397.

Yao, S.R., I.A. Merwin, and M.G. Brown. 2006. Root dynamics of apple rootstocks in a replanted orchard. HortScience 41:11491155.

Yao, S., I.A. Merwin, and M.G. Brown. 2009. Apple root growth, turnover, and distribution under different orchard groundcover management systems. HortScience 44:168-175.

Zhang, H., H.S. An, Y. Wang, X.Z. Zhang, and Z.H. Han. 2015. Low expression of PIN gene family members is involved in triggering the dwarfing effect in M9 interstem but not in M9 rootstock apple trees. Acta Physiol. Plant. $37: 104$. 